\title{
Water Supply Needs Analysis for the Remote Area of Sumba Island: a Resilience Strategy of Drought Disaster Risk Reduction
}

\author{
Rusnianti Rambu Lika1, Rr. M. I. Retno Susilorini2 ${ }^{2 *}$, Lintang Jata Angghita², \\ Dhiyan Krishna Wardhani ${ }^{2}$, Julius Ignatius Sinaga ${ }^{2}$ \\ ${ }^{1}$ Master Program of Environmental and Urban Studies, Faculty of Environmental Science and Technology, Soegijapranata \\ Catholic University, Jl. Pawiyatan Luhur IV/1, Bendan Dhuwur, Semarang 50234, Indonesia \\ ${ }^{2}$ Department of Infrastructure and Environmental Engineering, Faculty of Environmental Science and Technology, \\ Soegijapranata Catholic University, Jl. Pawiyatan Luhur IV/1, Bendan Dhuwur, Semarang 50234, Indonesia
}

*Corresponding author: ORCID 0000-0001-8531-7485

\begin{abstract}
Central Sumba Regency and Tana Mbanas village are the driest areas in Indonesia where water shortage happened and drought become annual event. Both Central Sumba Regency and Tana Mbanas village are facing problem of become growing population with limited water supply because of drought. Hence, this paper aimed to analyse water supply needs in Central Sumba Regency and Tana Mbanas village as resilience strategy in drought disaster risk reduction. This research investigated the water availability and sufficiency in Central Sumba Regency and Tana Mbanas village by water supply analysis. Existing population of Central Sumba Regency and Tana Mbanas village have been projected for the next 10 years using exponential method. Result of study found that projected 2030 water supply needs in Central Sumba Regency (214.52 1/sec) cannot fulfill the needs (only 2-163 1/sec) except the RWS Mambitul (228 1/sec). It is also found that water supply needs in Tana Mbanas village (3.40 1/sec) in 2030 is bigger than the capacity of potential ground water bore well $(<21 / \mathrm{sec})$ that located in SDM Waiurang. The water supply needs in Central Sumba Regency and Tana Mbanas village in 2030 cannot be provided by the water availability in those areas. This research meets conclusion that water supply needs analysis would become a resilience strategy in drought disaster risk reduction.
\end{abstract}

Keywords: water supply, Sumba drought, resilience strategy, disaster risk reduction.

\section{INTRODUCTION}

Sumba Island is drought prone area in Indonesia that most part of this island has about half a year of dryness without rainfall, included Central Sumba Regency [1]. As also mentioned by [2], drought is defined as an extended period of months or years where the precipitation is less than the annual average and cause water scarcity. Several areas of Indonesia are prone to drought due to geographical conditions and soil types (water porous). Another cause of drought is limited water resources as happened in Central Sumba Regency [3].

Central Sumba Regency is the driest area in Indonesia that is hilly and valley area as described by Fig 1 . This regency is about 500-1200 $\mathrm{m}$ above the sea level [1] with forest and savannah. This regency was established on 2007 by the Law of the Republic of Indonesia No. 3/2007 on the Establishment of Central Sumba Regency in East Nusa Tenggara Province. Central Sumba Regency consists of 5 sub-districts as described by Table 1 .

Table 1. Sub-districts of Central Sumba Regency [1]

\begin{tabular}{|c|c|c|}
\hline NO & SUBDISTRICT & $\begin{array}{c}\text { AREA } \\
\left(\mathbf{k m}^{2}\right)\end{array}$ \\
\hline 1 & Mamboro & 358.59 \\
\hline 2 & Umbu Ratu Nggay & 791.37 \\
\hline 3 & West Umbu Ratu Nggay & 272.05 \\
\hline 4 & South Katikutana & 368.34 \\
\hline 5 & Katikutana & 78.83 \\
\hline
\end{tabular}

The geological structure in Central Sumba Regency is Kaliangga formation which consists of yellowish and hollow limestone reefs and also corals and shells. Kaliangga formation is located in Mamboro sub-district and Umbu Ratu Nggay sub-districts. Another formation is established in some areas of Umbu Ratu Nggay sub-district, West Umbu Ratu Nggay sub-district, and South Katikutana district, it is Kananggar formations. These geological structures are porous that contribute to the dryness of the areas. 
International Journal of Engineering Research and Technology. ISSN 0974-3154, Volume 13, Number 10 (2020), pp. 2960-2967

(C) International Research Publication House. https://dx.doi.org/10.37624/IJERT/13.10.2020.2960-2967

Central Sumba Regency has dry and rainy seasons. In June to September, the wind blows from Australia. Since it doesn't contain much moisture, then it causes dry season. On the contrary, in December to March, wind blows from Asia and the Pacific Ocean and bringing lots of moisture and causes rainy season [1]. This situation changes every half year after the transition period in April-May and October-November. Instead of located closer to Australia, the wind that blows to Sumba Island from Asia and the Pacific Ocean looses much moisture and causes fewer rainy days in Central Sumba compared to regions closer to Asia. Therefore Central Sumba Regency becomes very dry region that only has 4 wet months
(January to March and December) as described by Fig 3 of the Isohyets rainfall map of Central Sumba Regency.

The development of Central Sumba Regency is very fast because of its capital, Waibakul. Many important roles of Waibakul are: (1) to become a center of services, collection, and distribution of goods in Central Sumba Regency; (2) to become regional transportation hub in the transportation system in Central Sumba Regency; (3) to become a growth centre for the hinterland and agricultural industries in Central Sumba Regency; and (4) to become central of government administrative affairs and public services to serve all sociocultural activities of Central Sumba Regency.

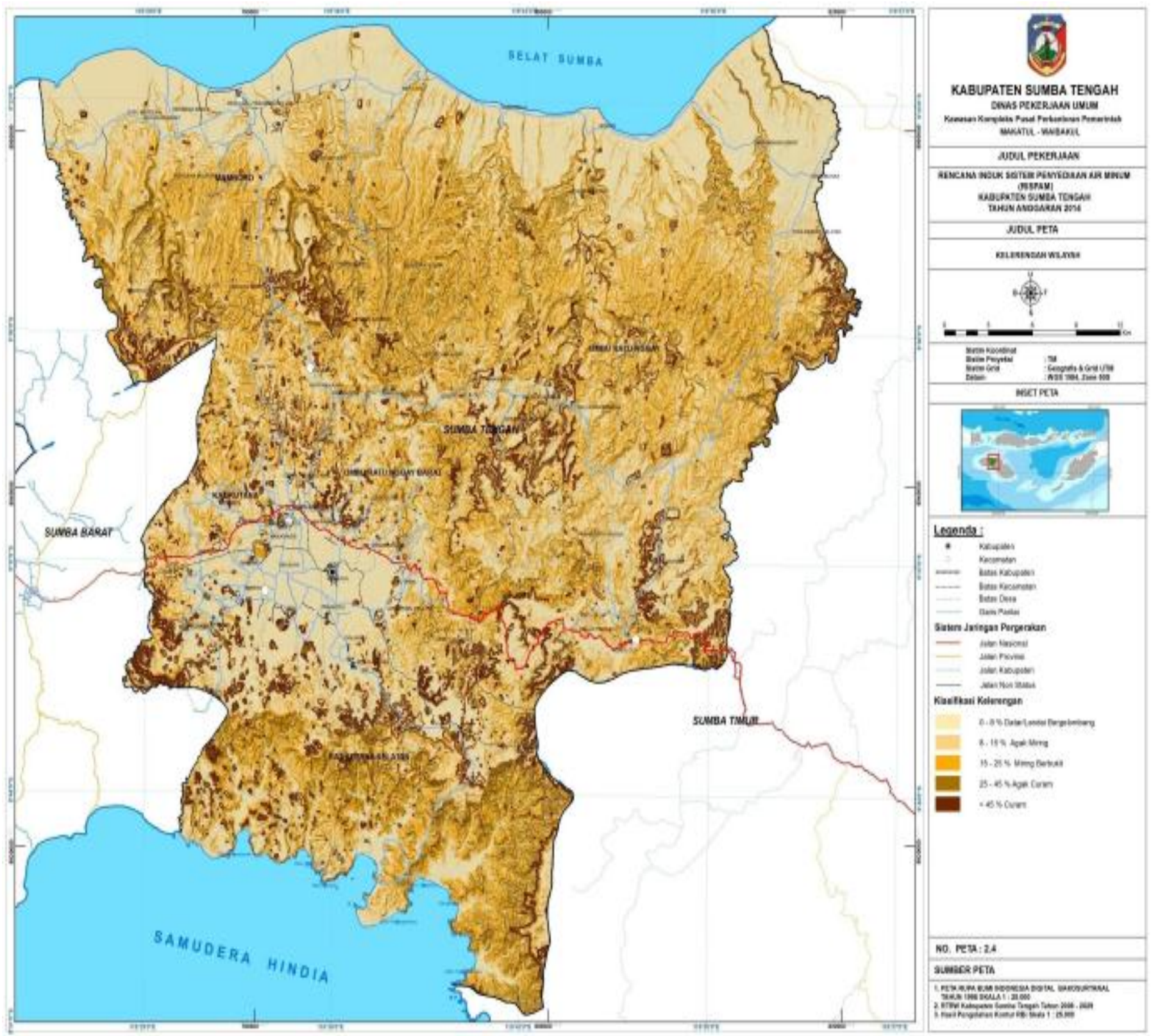

Fig 1. Slope Map of Central Sumba Regency (Central Sumba Regency Local Government) 


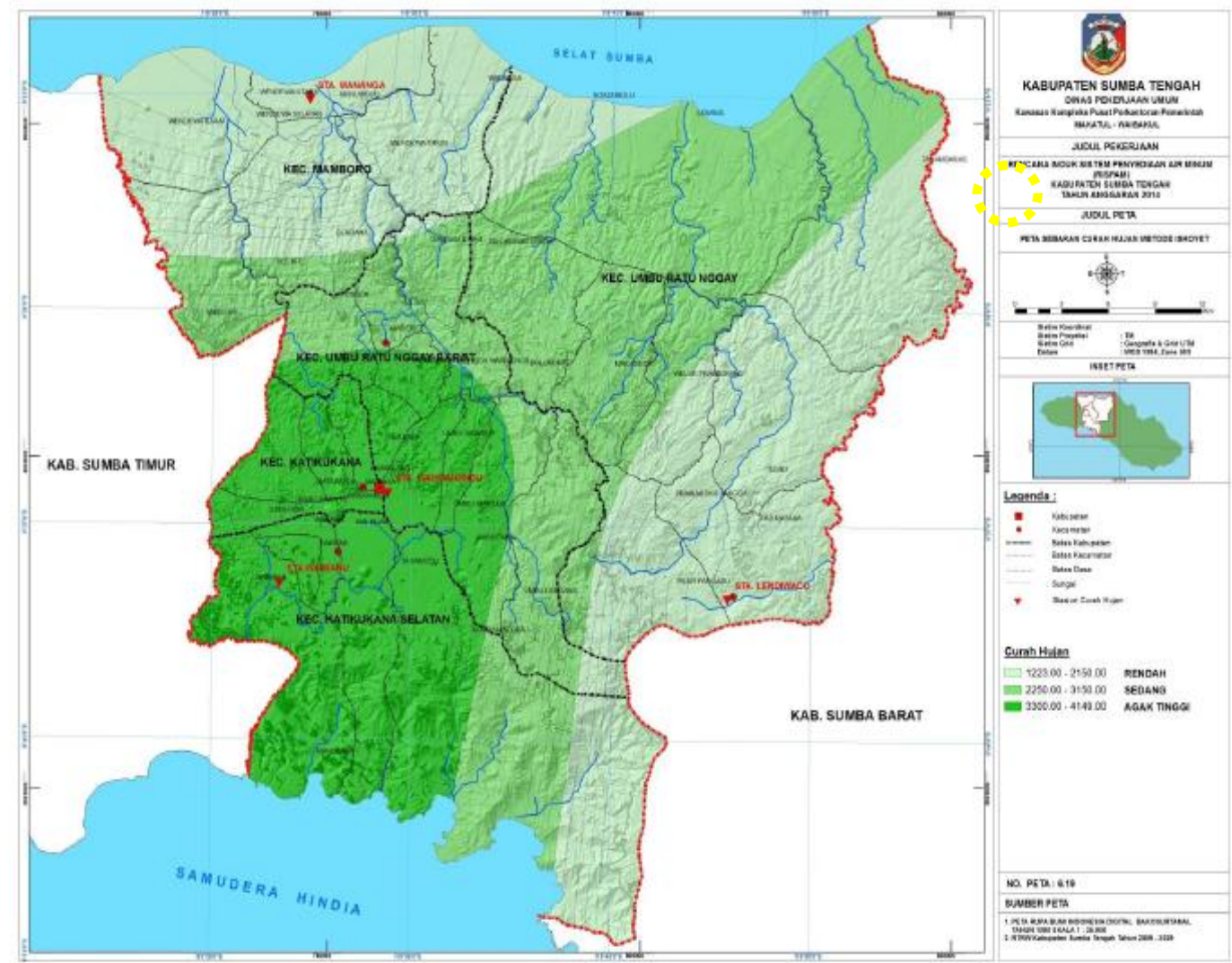

Fig 2. Isohyets Rainfall Distribution Map of Central Sumba Regency (Central Sumba Regency Local Government)

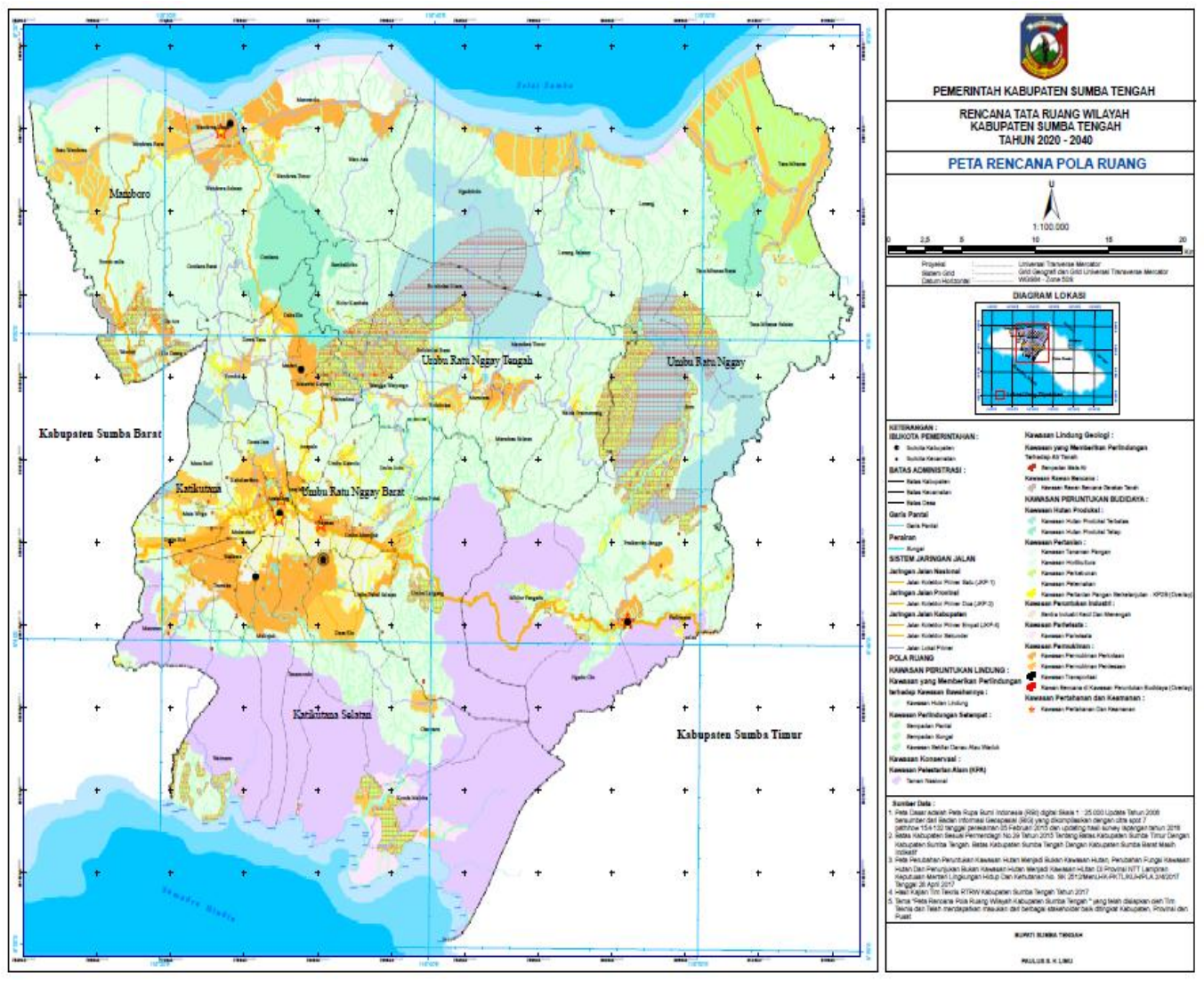

Fig 3. Spatial Planning Map of Central Sumba Regency (Central Sumba Regency Local Government) 


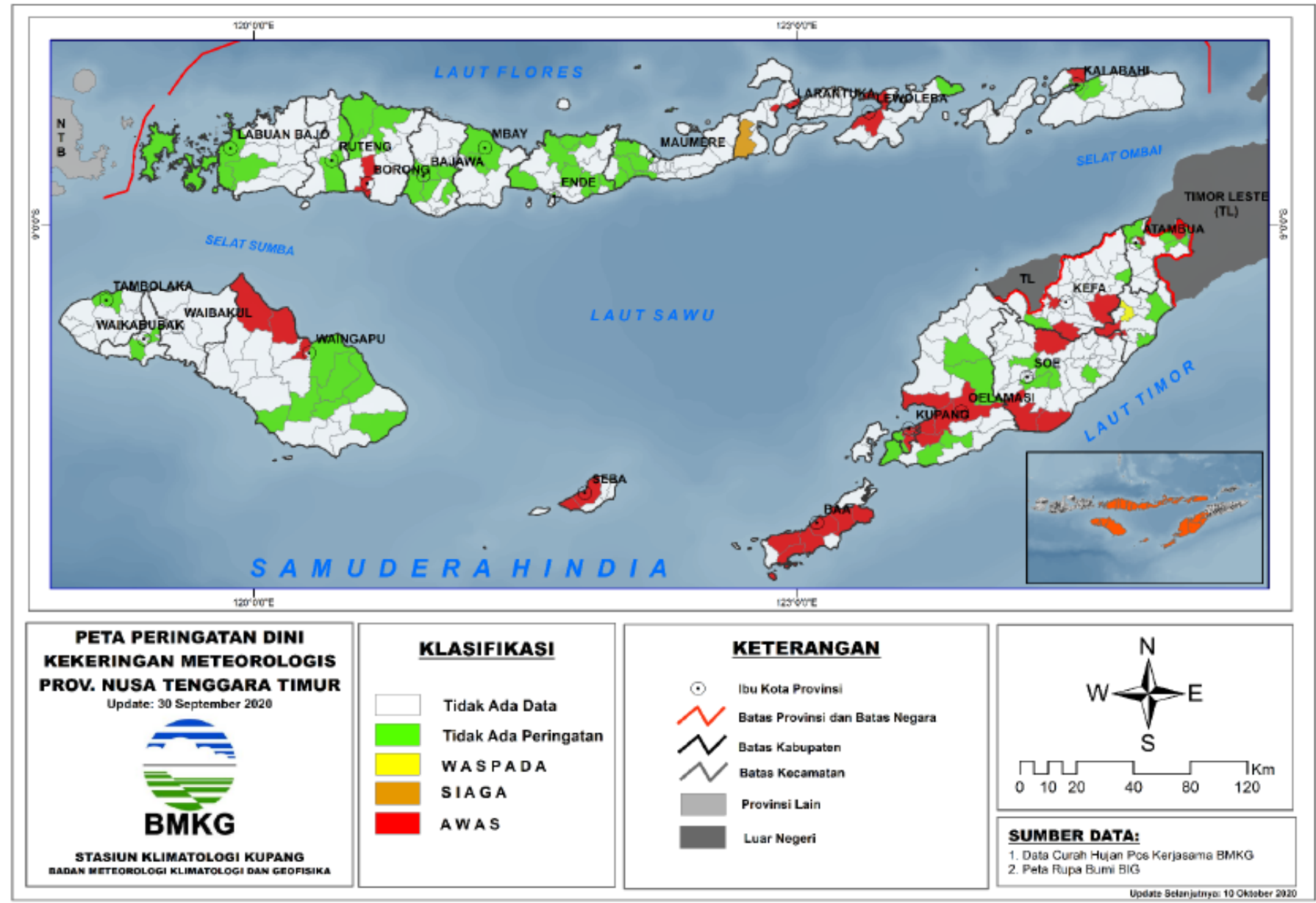

Fig 4. Early Warning System of Metrological Drought Map of East Nusa Tenggara Province (Kupang Climatological Station, National Meteorological, Climatological, and Geophysical Agency, 2020)

Drought event in Central Sumba Regency has brought devastating impact on individuals, groups and the wider community because of the water scarcity. Prior to drought events, local agencies announces early warning system of metrological drought as described by Fig 4 .

One driest village which is also remote area in Sumba Island is Tana Mbanas village. This village is located in the northern part of Umbu Ratu Nggay sub-district (Fig 2 the area with yellow circle dash line). It has little amount of rainfall that makes it dry in about 8 months in a year. It have been reported by $[4,5]$ that people of Tana Mbanas village has vulnerability to drought as well as lack of water supply and also water resources, even though there is government assistance in water supply program.

In 2019, population in Central Sumba Regency was 87,827 [1] while in Tana Mbanas village was 1,393 [6] which are going to grow in the near future. According to the criteria described by Table 2, Central Sumba Regency is small city, but it is still a 'busy city'. The main problem in Central Sumba Regency and Tana Mbanas village are growing population that have limited water supply because of drought. Due to drought events in those areas, there is no obvious disaster risk reduction (DRR) policy, especially resilience strategies and supporting infrastructures development to cope the problem. These issues are engaged to poor disaster risk reduction implementation that also caused by low quality of human resources and community participatory in addressing various environmental issues and people welfare.

It is emphasized that DRR requires commitment and participatory of stakeholders, mostly the society. Resilience, which part of DRR, will drive the ability to achieve sustainable development. Several studies reported strategies in disaster risk reduction, especially in resilience and adaptation in various disasters, methods, actions, etc. [2,7-23].

In case of water shortage in Central Sumba Regency and Tana Mbanas village [4,5], less participatory means less ability to cope with the water supply needs, especially in remote, disadvantaged, outer areas. Hence, it is important to analyse water supply needs as resilience strategy in drought disaster risk reduction, which is also purposed by this paper.

\section{METHOD}

This research investigated the water availability and sufficiency in Central Sumba Regency and Tana Mbanas village by water supply analysis. Calculation of water supply needs can be explained as follow.

1. Population projection for the next 10 years. Baseline of population in Central Sumba Regency and Tana Mbanas village is data of [1][6] 
International Journal of Engineering Research and Technology. ISSN 0974-3154, Volume 13, Number 10 (2020), pp. $2960-2967$

(C) International Research Publication House. https://dx.doi.org/10.37624/IJERT/13.10.2020.2960-2967

2. Water needs then being analyzed with domestic and non-domestic sectors parameters based on criteria of Cipta Karya General Directorate, Ministry of Public Work, Republic of Indonesia [19]

3. The water supply amount from point 2 should less than water availability

4. Water supply needs of Central Sumba Regency and Tana Mbanas village then being analyzed using calculation and data of [1][6][20]

Existing population of Central Sumba Regency [1] and Tana Mbanas village [6] have been projected for the next 10 years using exponential method by equation (1).

$$
P_{t}=P_{0} e^{r t}
$$

Where:

$\mathrm{P}_{\mathrm{t}} \quad=$ projected population after $\mathrm{t}$ years

$$
\begin{array}{ll}
\mathrm{P}_{0} & =\text { initial population } \\
\mathrm{r} & =\text { annual population growth rate } \\
\mathrm{t} & =\text { year since } \mathrm{P}_{\mathrm{t}} \text { to year of the estimate }
\end{array}
$$

Domestic sector analysis (as mentioned by point 2 in water supply needs calculation) is very important in determining future water supply needs. Since the analysis is carried out with population basis, the character of the region where the population live, i.e. a city, will also influence the water supply needs analysis. Therefore, water supply needs can be

\begin{tabular}{|c|c|c|c|c|c|c|}
\hline \multirow{3}{*}{ NO } & \multirow{3}{*}{ Description } & \multicolumn{5}{|c|}{ CITY CATEGORY BY POPULATION } \\
\hline & & $>1,000,000$ & $500,000-1,000,000$ & $100,000-500,000$ & $20,000-100,000$ & $<20,000$ \\
\hline & & Metropolitan City & Big City & Medium City & Small City & Village \\
\hline 1 & $\begin{array}{l}\text { Home Connection Unit } \\
\text { Consumption (SR) (litre/people/day) }\end{array}$ & $>150$ & $150-120$ & $90-120$ & $80-120$ & $60-80$ \\
\hline 2 & $\begin{array}{l}\text { Hydrant Unit Consumption (HU) } \\
\text { (litre/people/day) }\end{array}$ & $20-40$ & $20-40$ & $20-40$ & $20-40$ & $20-40$ \\
\hline & Non-Domestic Unit Consumption & & & & & \\
\hline & a. Small Enterprise (litre/unit/day) & $600-900$ & $600-900$ & & 600 & \\
\hline 3 & b. Big Enterprise (liter/unit/hari) & $1000-5000$ & $1000-5000$ & & 1500 & \\
\hline & c. Big Industry (litre/sec/ha) & $0.2-0.8$ & $0.2-0.8$ & & $0.2-0.8$ & \\
\hline & d. Tourism (litre/sec/ha) & $0.1-0.3$ & $0.1-0.3$ & & $0.1-0.3$ & \\
\hline 4 & Water Loss $(\%)$ & $20-30$ & $20-30$ & $20-30$ & $20-30$ & $20-30$ \\
\hline 5 & Peak Day Factor & $\begin{array}{l}1.15-1.25 \\
\text { daily }\end{array}$ & $\begin{array}{c}1.15-1.25 \\
\text { daily }\end{array}$ & $\begin{array}{l}1.15-1.25 \\
\text { daily }\end{array}$ & $\begin{array}{c}1.15-1.25 \\
\text { daily }\end{array}$ & $\begin{array}{c}1.15-1.25 \\
\text { daily }\end{array}$ \\
\hline 6 & Peak Hour Factor & $\begin{array}{l}1.75-2.0 \\
\text { max-day }\end{array}$ & $\begin{array}{l}1.75-2.0 \\
\text { max-day }\end{array}$ & $\begin{array}{l}1.75-2.0 \\
\text { max-day }\end{array}$ & $\begin{array}{c}1.75 \\
\text { max-day }\end{array}$ & $\begin{array}{c}1.75 \\
\text { max-day }\end{array}$ \\
\hline 7 & Population per SR & 5 & 5 & 5 & 5 & 5 \\
\hline 8 & Population per HU & 100 & 100 & 100 & $100-200$ & 200 \\
\hline 9 & $\begin{array}{l}\text { Time Press on Distribution } \\
\text { Provisioning (meter) }\end{array}$ & 10 & 10 & 10 & 10 & 10 \\
\hline 10 & Operation Hour (hour) & 24 & 24 & 24 & 24 & 24 \\
\hline 11 & $\begin{array}{l}\text { Reservoir Volume (\% max day } \\
\text { demand) }\end{array}$ & $15-25$ & $15-25$ & $15-25$ & $15-25$ & $15-25$ \\
\hline 12 & SR : HU & $50: 50-80: 20$ & $50: 50-80: 20$ & 80:20:00 & 70:30:00 & 70:30:00 \\
\hline 13 & $\begin{array}{l}\text { Service Coverage } \\
(\%)\end{array}$ & 90 & 90 & 90 & 90 & 70 \\
\hline
\end{tabular}
calculated based on criteria of city category by population as defined by Table 2 .

Table 2. Water Supply Needs Based on City Category by Population [19] 


\section{RESULT AND DISCUSSION}

Analysis has been conducted for projecting the water supply needs both in Central Sumba Regency and Tana Mbanas village as described by Table 3 . It is found that for 2030 , Central Sumba Regency will need water supply of 214.52 1/sec while Tana Mbanas village of 3.40 1/sec. For capital and urban area of Central Sumba Regency, there are 7 potential Raw Water Systems (RWS) [20] as reported by Table 4.

Projecting 2030 water supply needs in Central Sumba Regency (214.52 1/sec), it seems that most RWS in Central Sumba Regency cannot fulfill the needs (only 2-163 1/sec) except the RWS Mambitul (228 1/sec). It should be noted also that in this case, the population growth rate linear by 0.97 and the capacity of RWS remain. From Map of Spatial Planning (Fig 3), the development plan of industrial and settlement zones are dominating. Therefore, the water supply needs can be higher than the one has been projected in this study. Since June-October is dry period as well as drought event, then some area of Mamboro sub-district and Umbu Ratu Nggay sub-district (included Tana Mbanas village) have low rainfall intensity [1].

Result of analysis also shows that in 2030, the water supply needs in Tana Mbanas village $(3.40 \mathrm{l} / \mathrm{sec})$ is bigger than the capacity of potential ground water bore well $(<21 / \mathrm{sec})$ that located in SDM Waiurang. In drought event, Tana Mbanas village has very low rainfall intensity [1] that causes the water shortage.

Master Plan of Drinking Water System of Central Sumba Regency of 2015-2035 [20] has to be evaluated in these years due to the emergence of water shortage, climate change that cause drought, and population increase. Proper water supply infrastructure, rain harvesting method, and water resources management will support drought disaster risk reduction and guarantee the availability of water supply for the next 10 years or even 20 years.

Table 3. Water Supply Needs Analysis for Central Sumba Regency and Tana Mbanas Village

\begin{tabular}{|c|c|c|c|c|c|c|c|}
\hline NO & LOCATION & $\begin{array}{c}\text { CITY/ } \\
\text { VILLAGE }\end{array}$ & $\begin{array}{l}\operatorname{AREA}[1][6] \\
\qquad\left(\mathbf{k m}^{2}\right)\end{array}$ & $\begin{array}{l}\text { POPULATION } \\
\text { (PRESENT, } \\
\text { 2020) [1][6] }\end{array}$ & $\begin{array}{c}\text { POPULATION } \\
\text { (PROJECTED,2030) }\end{array}$ & $\begin{array}{c}\text { WATER } \\
\text { SUPPLY } \\
\text { NEEDS } \\
\text { (l/day) } \\
\text { (PROJECTED, } \\
\text { 2030) }\end{array}$ & $\begin{array}{l}\text { WATER SUPPLY } \\
\text { NEEDS } \\
\text { (1/sec) }\end{array}$ \\
\hline 1 & Central Sumba Regency & city & 187.87 & 87,827 & 231,683 & $18,534,619.84$ & 214.52 \\
\hline 2 & Tana Mbanas & village & 69.25 & 1,393 & 3,675 & $293,972.53$ & 3.40 \\
\hline
\end{tabular}

Table 4. Raw Water Systems in capital and urban area of Central Sumba Regency [20]

\begin{tabular}{lccl}
\hline NAME OF RWS & $\begin{array}{c}\text { WATER } \\
\text { FLOW (LPS) }\end{array}$ & $\begin{array}{c}\text { TYPE OF } \\
\text { INTAKE }\end{array}$ & SOURCE AND SYSTEM \\
\hline RWS Waikadika & 44 & Broncaptering & Water spring, distribution system by pump and collecting pond \\
RWS Sotu & 128 & Broncaptering & Surface runoff, distribution system by gravitation \\
RWS Mambitul & 228 & Broncaptering & Water spring, distribution system by pump and collecting pond \\
RWS Pamalar & 119 & Broncaptering & Surface runoff, distribution system by gravitation \\
RWS Kamelimabu & 2 & Broncaptering & Surface runoff, distribution system by gravitation \\
RWS Hikur & 22 & Broncaptering & Water spring, distribution system by pump and collecting pond \\
RWS Langgaliru & 163 & Broncaptering & Water spring, distribution system by pump and collecting pond \\
\hline
\end{tabular}




\section{CONCLUSION}

Water shortage is a crucial problem during the drought event. Hence, the needs of water supply should be analysis properly for the next 10 years projection. It was projected that that population of Central Sumba Regency and Tana Mbanas village will increase $263.79 \%$, while the needs of water supply increase $1.32 \%$ compared to the capacity of available water resources. The water supply needs in Central Sumba Regency and Tana Mbanas village in 2030 cannot be provided by the water availability in those areas. Therefore, it is important to evaluate Master Plan of Drinking Water System of Central Sumba Regency of 2015-2035 due to the emergence of water shortage, climate change that cause drought, and population increase. This research meets conclusion that water supply needs analysis would become resilience strategy in drought disaster risk reduction.

\section{ACKNOWLEDGMENT}

We gratefully thank to the financial support of Ministry of Research and Technology/National Research and Innovation Agency, Republic of Indonesia, of National Research Grant on Master Thesis Research Grant Scheme in 2020 (Decree No. 26 /E1/KPT/2020 and No. 10/E1/Kpt/2020 and also Contract No. 082/SP2H/AMD/LTDRPM/2020, No. 008/ LL6/PGSP2H/PL.I/2020, No. 00549/H.2/LPPM/III/2020).

\section{REFERENCES}

[1] BPS Kabupaten Sumba Barat. Kabupaten Sumba Tengah dalam Angka (Central Sumba Regency in Figures) 2020. BPS Kabupaten Sumba Barat; 2020.

[2] Udmale P, Ichikawa Y, Manandhar S, Ishidaira H, Kiem AS. Farmers' perception of drought impacts, local adaptation and administrative mitigation measures in Maharashtra State, India. Int J Disaster Risk Reduct 2014;10:250-69. https://doi.org/10.1016/j.ijdrr.2014.09.011.

[3] Adimihardja A. Strategi mempertahankan multifungsi pertanian di indonesia. J Litbang Pertan 2006.

[4] Susilorini RMIR, Lika RR, Sriyana, Angghita LJ, Sinaga JI. Gender Mainstreaming in Drought Disaster Risk Reduction. ICOSTA 2020, Medan, Indonesia: Universitas Negeri Medan; 2020.

[5] Rambu Lika R. Strategi Masyarakat dalam Mengatasi Kekeringan di Desa Tana Mbanas Kabupaten Sumba Tengah, Provinsi Nusa Tenggara Timur Tesis. Soegijapranata Catholic University, 2020.

[6] BPS Kabupaten Sumba Barat. Kecamatan Umbu Ratu Nggay dalam Angka 2020. BPS Kabupaten Sumba Barat; 2020 .

[7] Djalante R, Lassa J, Setiamarga D, Sudjatma A, Indrawan M, Haryanto B, et al. Review and analysis of current responses to COVID-19 in Indonesia: Period of January to March 2020. Prog Disaster Sci
2020;6:100091.

https://doi.org/10.1016/j.pdisas.2020.100091.

[8] Matrix DR. Indonesia's Cities towards Smart and Resilient City 2020:2018-21.

[9] Mahendra WA, Armono HD, Sambodho K. Studi Analisa Ketahanan Masyarakat Pesisir Cilacap Terhadap Bencana Tsunami. J Tek Pomits 2013.

[10] Susilorini RRMIR, Vidayanti D, Fitra HA, Santosa B. Can we adapt to tidal flooding? AIP Conf Proc 2019;2114. https://doi.org/10.1063/1.5112454.

[11] I Retno Susilorini RM, William SS, Kartikowati S, Hendri Setiawan M, Hardian LP, Kurniawan E. Masonry Walls Retrofitting with Eco-Concrete Bricks in Tidal Flooding Prone Area. vol. 13. 2020.

[12] Retno Susilorini MI, Febrina R, Fitra HA. Evaluating couple simple shear wall as low-cost masonry wall strengthening by rebound hammer test. Int J Eng Res Technol 2020;13:600-7.

[13] Retno Susilorini MI, Suryanto R, Pramana Y. Carbohydrate polymers for green multi-purpose mortar. Int J Eng Res Technol 2020;13:580-5.

[14] Febrina R, Evan DK, Afriani L, Retno RMI, Susilorini, Fitra HA. The analysis of Tsunami evacuation route based on geographic information system: A case study in the coast of Lampung Bay. IOP Conf Ser Mater Sci Eng 2020;807. https://doi.org/10.1088/1757$899 X / 807 / 1 / 012022$.

[15] Twigg J. Characteristics of a Disaster - Resilient Community. vol. 7. 2013.

[16] Mendis WSW, De Silva S, De Silva GHMJS. Performance and Retrofitting of Unreinforced Masonry Buildings against Natural Disasters - A Review Study. Eng J Inst Eng Sri Lanka 2014;47:71. https://doi.org/10.4038/engineer.v47i3.6896.

[17] Susilorini RMIR, Harnadi B, Wardhani DK, Angghita LJ, Febrina R, Fitra HA. From Field to Virtual: Developing Hybrid-Learning Media of Earthquake and Tsunami Disaster Resilience Strategy of Fishing Village Community in Bandar Lampung. E-Proceedings Int. Conf. Innov. Educ. Oppor. Challenges Southeast Asia, Semarang: Soegijapranata Catholic University; 2019, p. 267-87.

[18] Susilorini RMIR, Pamudji AK, Ismail A, Amasto AH. Alert and Response of Earthquake and Tsunami for Community Based Disaster Risk Reduction. ICOSTA 2020, Medan, Indonesia: Universitas Negeri Medan; n.d.

[19] Direktorat Jenderal Cipta Karya. Analisis Kebutuhan Air Bersih. Jakarta, Indonesia: Departemen Pekerjaan Umum; 1996.

[20] Dinas Pekerjaan Umum Kabupaten Sumba Tengah. Rencana Induk Pengembangan Sistem Penyediaan Air Minum Kabupaten Sumba Tengah Tahun 2015-2035. 2015. 
[21] Susilorini, R.M.I.R., Suwarno, D., Santosa, B., Putra, L.H., Kurniawan, E. Rebound Hammer Test result of old repaired masonry wall using premixed mortar additive in tidal flooding prone area. AIP Conference Proceedings. 2018. 1977(June). Pp. 1-6. DOI:10.1063/1.5042982.

[22] Susilorini, R.M.I.R., Santosa, B., Rejeki, V.G.S., Riangsari, M.F.D., Hananta, Y.D. The increase of compressive strength of natural polymer modified concrete with Moringa oleifera. AIP Conference Proceedings. 2017. 1818. DOI:10.1063/1.4976923.

[23] Rr. M. I. Retno Susilorini, Budi Santosa, N. Febri Satrio, R.P.B. Compressive and Splitting Tensile Strength of Polymer Modified Concrete Using Amylum and Honey. Journal of Engineering and Applied Science. 2018. 13(17). Pp. 7192-7197. DOI:http://dx.doi.org/10.3923 /jeasci.2018.7192.7197.

[21] Susilorini, R.M.I.R., Suwarno, D., Santosa, B., Putra, L.H., Kurniawan, E. Rebound Hammer Test result of old repaired masonry wall using premixed mortar additive in tidal flooding prone area. AIP Conference Proceedings. 2018. 1977(June). Pp. 1-6. DOI:10.1063/1.5042982.

[22] Susilorini, R.M.I.R., Santosa, B., Rejeki, V.G.S., Riangsari, M.F.D., Hananta, Y.D. The increase of compressive strength of natural polymer modified concrete with Moringa oleifera. AIP Conference Proceedings. 2017. 1818. DOI:10.1063/1.4976923.

[23] Rr. M. I. Retno Susilorini, Budi Santosa, N. Febri Satrio, R.P.B. Compressive and Splitting Tensile Strength of Polymer Modified Concrete Using Amylum and Honey. Journal of Engineering and Applied Science. 2018. 13(17). Pp. 7192-7197. DOI:http://dx.doi.org/10.3923 /jeasci.2018.7192.7197. 